\title{
Distribution of myopia in aphakic retinal detachments
}

\author{
MONTAGUE RUBEN AND PUSHPA RAJPUROHIT \\ From the Contact Lens and Prosthetics Department, Moorfields Eye Hospital, London
}

The aetiology of retinal detachment after lens extraction requires analysis to determine common factors. According to Treister (I972) an increased incidence is due to the use of chymotrypsin. Shapland (1934) quotes an overall incidence of 2.2 per cent using the extracapsular technique. He thought it to be higher in myopic aphakia but he gave no figures. Hyams, Bialik, and Neumann (r975) give an incidence of 6.7 per cent for myopia above $-6 \cdot 00$. The factors that may be considered statistically are age, sex, surgical technique, type of anaesthesia, and precataract refractive error.

Details of surgical technique are difficult to analyse, but the essential procedures may be grouped easily into extra- and intracapsular removal of the lens, cryoextraction, and use of enzyme. Complications such as vitreous loss may also be clearly indicated. Results may be analysed by using corrected acuity as the yardstick, though the incidence of poor acuity after extraction is likely to be high in degenerative myopia, complicated cataracts, traumatic cataracts, and infantile cataracts. The results analysed in this paper exclude infantile cataracts, in which the incidence of detachment is high (Shapland, 196I) and the acuity poor (Ruben, 1969).

By analysing the results of almost 1000 cataract extractions for the incidence of detachment and for visual acuity and a random group of them for refractive error power corrections we hoped to show the role of myopia in the incidence of aphakic retinal detachment. In order to obtain these results a schematic aphakic eye was introduced so that the precataract refractive state could be easily calculated.

\section{Patients and methods}

The operation records and in- and outpatient notes were studied of all patients operated on for cataract by the corneo-scleral section lens extraction procedure at the High Holborn Branch of Moorfields Eye Hospital in the three years 1967-9. All aspirations and washouts were excluded. The following information on each

Address for reprints: M. Ruben, FRCS, Department of Contact Lens and Prosthetics, Moorfields Eye Hospital, High Holborn, London WCIV $7 \mathrm{AN}$ patient was noted: age at time of operation; sex; details of operation (general anaesthetic, extra- or intracapsular or cryoextraction, forceps, type of section, vitreous loss); postoperative data; best acuity with spectacles; preoperative refractive state (when recorded); detachment of retina in the postoperative aphakic state or in the phakic state at time of operation; site of retinal tears; acuity after retinal surgery; referral of patients for fitting with contact lens.

\section{SCHEMATIC APHAKIC EYE}

A schematic aphakic eye was used to relate the postoperative to the precataract refractive state.

Given an average phakic power of +60.00 and an average keratometry of $7.80(R I=I \cdot 37)$, the average spectacle power at a back vertex distance (BVD) of I5 $\mathrm{mm} \equiv+13.50$. Thus for each refraction postoperatively the equivalent sphere was found and the ocular refraction calculated $(B V D=15 \mathrm{~mm})$. The difference between the two gives the preoperative refractive state. It would be unwise for these figures to assume a tolerance greater than \pm 1.00 and therefore the grouping of the results will be in 5 dioptres.

The following is an example of the calculation.

Spectacle refraction $=+14.00 /+2.00 \times 180\left(B V D\right.$ I $\left._{5}\right)$; equivalent sphere refraction $=+15.00$; schematic spectacle refraction $=+13.50$; therefore the preoperative refractive state $=+I \cdot 50$ hypermetropia (no effective power correction for ocular refraction unless over 5 dioptres).

\section{Results}

The results are given, first, as general data and, secondly, those that specifically refer to aphakic detachment of the retina.

\section{GENERAL DATA}

The total number of operations was 944 (Table I). For each year the numbers were 332,350 , and 260 respectively. Of the total number 896 were unilateral operations and within the period 48 patients had the other cataract removed. Thus 944 cataract operations represent 896 patients. Their average age was 65 and 448 were men and 448 were women.

During the period 1967-69 there was a rapid increase both in the use of general anaesthesia and of the cryo probe for lens extraction (Table II). 
Table I Numbers of cataract operations, patients, and aphakic detachments

\begin{tabular}{|c|c|c|c|}
\hline Year & $\begin{array}{l}\text { No. of } \\
\text { patients }\end{array}$ & $\begin{array}{l}\text { No. of } \\
\text { operations }\end{array}$ & $\begin{array}{l}\text { No. (per cent) } \\
\text { of detachments }\end{array}$ \\
\hline 1967 & 304 & 332 & I $8(5 \cdot 4)$ \\
\hline I 968 & 344 & $35^{\circ}$ & $19(5 \cdot 4)$ \\
\hline 1969 & 248 & 262 & $17(6 \cdot 4)$ \\
\hline Total & 896 & $944^{*}$ & $54(5 \cdot 7)$ \\
\hline
\end{tabular}

*Unilateral $=896(95$ per cent $)$; bilateral $=48$ ( 5 per cent $)$

Table II Use of general anaesthesia and cryoextraction for lens extraction in each of the three years $1967-9$

\begin{tabular}{|c|c|c|c|}
\hline Year & $\begin{array}{l}\text { No. of } \\
\text { operations }\end{array}$ & $\begin{array}{l}\text { General } \\
\text { anaesthesia } \\
\text { No. (per cent) }\end{array}$ & $\begin{array}{l}\text { Cryoextraction } \\
\text { No. (per cent) }\end{array}$ \\
\hline 1967 & 332 & $53(12)$ & 34 (10) \\
\hline I 968 & 350 & $287(82)$ & I9I (54) \\
\hline 1969 & 262 & $220(84)$ & $262(100)$ \\
\hline Total & $944^{*}$ & 560 & 487 \\
\hline
\end{tabular}

*Extracapsular extraction 53 ( 5.6 per cent $)$; intracapsular extraction 89 I (94.3 per cent). Inferior section used in 8 glaucoma eyes

Table III Best postoperative visual acuity in 944 cases of lens extraction

\begin{tabular}{|c|c|}
\hline Acuity & $\begin{array}{l}\text { No. (per cent) } \\
\text { of cases }\end{array}$ \\
\hline $\mathrm{HM}$ to $\mathrm{CF}$ & $88(9 \cdot 6)$ \\
\hline $6 / 60-6 / 36$ & I IO (I I 9$)$ \\
\hline $6 / 24-6 / 18$ & $210(22 \cdot 9)$ \\
\hline $6 / 12-6 / 9$ & $340(37 \cdot 0)$ \\
\hline $6 / 6-6 / 5$ & $170(18.6)$ \\
\hline Not known* & $26(2 \cdot I)$ \\
\hline Total & $944(100)$ \\
\hline
\end{tabular}

These years are therefore relevant to any discussion on the aetiology of retinal detachment in aphakia. Only eight cases had an inferior section and this number will not substantially affect the percentage incidence in the remaining 936 eyes.

The best postoperative spectacle correction findings are based on figures for only 918 eves (Table III). These results will be discussed in relation to the phakic equivalent refractive state subsequently. Cases are grouped according to the visual acuities recorded in their notes by medical and sight-testing optician staff. When complications prevented measurement of acuity or none was given blindness could not be assumed. But it must be assumed that many of the 26 cases in which acuity was not known or unrecorded were, in fact, blind eyes. For the purposes of useful vision a corrected acuity better than $6 / 24$ is a 'watershed', and 77 per cent fall within this category.

In 46 patients refractions done before operation revealed myopia between -10.00 and -20.00 (Table IV), and this will be commented on in relation to the estimated number of similar myopes for the whole group (Table V) and the figures quoted in Tables VI to VIII, which analyse the groupings of myopia in aphakia with detachment of retina.

Analysis of the II 7 randomly selected refractions, using the schematic aphakic eye and its spectacle correction of +13.50 , showed that 78.7 per cent were in the refractive group -4.00 to +4.00 . This method can only approximate the precataract refraction state since the schematic eye calculations assume constants for BVD and refractive index $(\mathrm{RI})$ and tolerances of refraction subjective testing, which are not known. For the purposes of this analysis 19.5 per cent were myopic over -5.00 and 7.70 per cent myopic over -10.00 in the precataract state.

The total number of retinal detachments occurring in the postoperative phase was 54 or 5.7 per cent of the total eyes operated on and the yearly analysis was $5.4,5 \cdot 4$, and 6.4 (Table I). In some

Table IV Patients with high preoperative myopia between -10.00 and -20.00

\begin{tabular}{lll}
\hline Year & & No. \\
\cline { 1 - 1 } 1967 & & I5 \\
1968 & & 17 \\
1969 & 14 \\
\hline Total & & 46 \\
\hline
\end{tabular}

Table V Phakic equiralent refractive state in I 7 randomly selected eyes with extrapolation for 944 eyes

\begin{tabular}{|c|c|c|c|}
\hline \multicolumn{2}{|c|}{ Refraction ( 117 eyes) } & \multirow{2}{*}{$\begin{array}{l}\text { No. } \\
\text { (per cent) } \\
\text { of cases }\end{array}$} & \multirow{2}{*}{$\begin{array}{l}\text { Extra- } \\
\text { polation } \\
\text { (944 eyes) }\end{array}$} \\
\hline Phakic equivalent & Aphakic & & \\
\hline $\begin{array}{l}-10.00 \text { to }-20.00 \\
-5.00 \text { to }-9.00 \\
-4.00 \text { to } 00 \\
+1.00 \text { to }+4.00 \\
\text { Over }+5.00\end{array}$ & $\begin{array}{l}+3.50 \text { to }-6.50 \\
+4.50 \text { to }-8.50 \\
+9.50 \text { to }-13.50 \\
+14.50 \text { to }-17.50 \\
\text { Over }-18.50\end{array}$ & $\begin{aligned} & 9(7 \cdot 7) \\
& 15(12 \cdot 8) \\
& 78(66 \cdot 6) \\
& 14(12 \cdot 1) \\
& 1(1 \cdot 0)\end{aligned}$ & $\begin{array}{r}69 \\
119 \\
640 \\
108 \\
8\end{array}$ \\
\hline Total & & $117(100)$ & 944 \\
\hline
\end{tabular}


instances the detachment was bilateral. Thus there were 43 patients with 54 detachments, the incidence of bilateral detachment being almost 20 per cent of the detachment group. The sex distribution was men 65 per cent, women 35 per cent (Table VI). A male predominance was also noted by Shapland (1934). The average age (59) of the patients with aphakic detachments was lower than that of the whole group. This high incidence of bilaterality has also been noted by Kanski (personal communication).

In the detachment group 33 had known refractive powers. Of those aphakic patients in this study who had retinal detachments and whose refractions were known, no fewer than 16 out of 33 (50 per cent) had a refractive error of more than -ro dioptres (Table VIII). The distribution of refractive errors in the whole group of 944 eyes can be deduced by reference to a study of the data in a sample of II 7 eyes in which the refractions were known (Table V).

It is possible to calculate from these data the incidence of retinal detachment in myopes of - Io dioptres or more. It is known that 50 per cent of all patients with detachments had refractive errors of -1o dioptres or more. This would give an expected figure in the whole sample of 944 of 27 eyes ( 50 per cent of the detachments) out of 69 eyes

Table VI Data on 43 patients (54 eyes) with aphakic retinal detachments (one traumatic detachment excluded)

\begin{tabular}{ll}
\hline Sex & \\
Male & $28(65$ per cent $)$ \\
Female & I 5 (35 per cent) \\
Age (years) & \\
Average & 59 \\
Range & $30-86$ \\
Detachment & \\
Unilateral & 43 (80 per cent) \\
Bilateral & I I $(20$ per cent $)$ \\
\hline
\end{tabular}

Table VII Incidence of myopia in 54 eyes with aphakic retinal detachments

\begin{tabular}{|c|c|c|}
\hline $\begin{array}{l}\text { Preoperative } \\
\text { refraction }\end{array}$ & $\begin{array}{l}\text { No. of } \\
\text { cases }\end{array}$ & $\begin{array}{l}\text { Percentage } \\
\text { (of } 33 \text { cases) }\end{array}$ \\
\hline Emmetropia & 8 & $24\}$ \\
\hline 0 to -4.00 & 6 & $18\}$ \\
\hline-5.00 to -9.00 & 3 & 376 \\
\hline-10.00 to -20.00 & I 633 & $50 \int^{50}$ \\
\hline Not known & 21 & \\
\hline Total & 54 & \\
\hline
\end{tabular}

Table VIII Probability of aphakic retinal detachments according to refractive error

\begin{tabular}{ll}
\hline Refraction & $\begin{array}{l}\text { Incidence } \\
\text { (per cent) }\end{array}$ \\
\cline { 2 - 2 } In refractive groups & \\
0 to -4.00 & 3.5 \\
-5.00 to -9.00 & $4 \cdot 2$ \\
-10.00 to -20.00 & $40 \cdot 0$ \\
\hline
\end{tabular}

Table IX Operation data in 54 cases of aphakic detachment

\begin{tabular}{|c|c|}
\hline Data & $\begin{array}{l}\text { No. (per cent) } \\
\text { of cases }\end{array}$ \\
\hline Intracapsular & $52(96)$ \\
\hline Extracapsular & $2(4)$ \\
\hline Cryo probe & $32(59)$ \\
\hline Forceps & $8(15)$ \\
\hline Chymotrypsin & $19(35)$ \\
\hline Vitreous loss & $6(\mathrm{II})$ \\
\hline
\end{tabular}

(the calculated number of eyes in the whole sample of aphakics with refraction of -10 dioptres or more). This gives an incidence of retinal detachment in aphakia, in which the original refraction was -10 dioptres or more, of 27 out of 69 , almost 40 per cent. The expected incidence in the other refractive groups can be similarly calculated (Table VIII).

Aetiological factors apart from myopia require analysis of the operation details (Table IX) and will be dealt with in discussion. But it is significant that for the years 1967,1968 , and 1969 (Table I) the incidence of detachment does not vary more than one per cent although the change from forceps to cryo probe extractions was more than threefold. The intra- extra-capsular extraction ratio and use of the cryo probe is not very different from that shown in Table II for the whole series and therefore not significant. Vitreous loss in the detachment group is significant (I I per cent) since the figures for the whole series were less than i per cent.

The period for analysis began in 1967 from the date of first operation and the case notes were studied up to the time of the survey (December 1975). We could therefore plot the time factor in the incidence of detachment (Table X). In 33 cases where information was clearly obtained twothirds occurred in the first postoperative year and nearly one-third in the second.

While we did not originally intend to obtain information about the site of the retinal break this was clearly indicated in 36 eyes and the results are given (Table XI). Half of the eyes had a com- 
Table X Time of onset of retinal detachment after cataract extraction

\begin{tabular}{|c|c|c|c|c|}
\hline $\begin{array}{l}\text { Time } \\
\text { (months) }\end{array}$ & $\begin{array}{l}\text { No. of } \\
\text { cases }\end{array}$ & $\begin{array}{l}\text { First } \\
\text { year }\end{array}$ & $\begin{array}{l}\text { Second } \\
\text { year }\end{array}$ & $\begin{array}{l}\text { Third year } \\
\text { or more }\end{array}$ \\
\hline $\mathbf{I}$ & 6) & & & \\
\hline $\begin{array}{l}4 \\
8\end{array}$ & $\left.\begin{array}{l}7 \\
6\end{array}\right\}$ & 21 & & \\
\hline 12 & 2) & & & \\
\hline 24 & 10 & & 10 & \\
\hline$>24$ & 2 & & & 2 \\
\hline
\end{tabular}

Table XI Site of break in retina in 36 eyes

\begin{tabular}{|c|c|}
\hline Site & No. of cases \\
\hline Temporal & 6 \\
\hline Upper & $\mathbf{I}$ \\
\hline Lower & 5 \\
\hline Nasal & 12 \\
\hline Upper & 2 \\
\hline Lower & 10 \\
\hline Complete & I 8 \\
\hline Total & 36 \\
\hline
\end{tabular}

plete detachment. But of the remaining 18 , six showed temporal and 12 nasal retinal breaks. One was upper temporal, five lower temporal, Io lower nasal, and two upper nasal-a pronounced preponderance on the lower retina and nasal side. There were insufficient data to relate this to vitreous wound inclusion and secondary retraction of vitreous.

Comparison of the visual acuities after retinal surgery (Table XII) with those for aphakia (Table III) shows a substantial loss in central acuity and almost fourfold incidence of blindness (less than $6 / 60)$.

\section{Discussion}

The use of the cryo probe and general anaesthesia for lens extraction increased almost fivefold in the period 1967-68, yet the incidence of detachment remained essentially the same. According to Treister (1972) chymotrypsin increases the incidence of detachments. In our group of 944 eyes enzyme was used for extractions in 32 per cent of cases and the incidence of aphakic retinal detachment was 5.7 per cent. Shapland (1934), however, quotes an incidence of retinal detachment of $2 \cdot 2$ per cent for extracapsular extractions, and his figures are derived from hospitals historically associated and with similar populations. The essential differences between the philosophy of cataract management and surgical technique in the ra20s and the r 960 s are shown in Table XIII. The proportion of high myopia in Shapland's patients and in our series cannot be statistically compared since early figures are not available. While there is no reason to believe that Shapland's figure of $\mathbf{2 \cdot 2}$ per cent includes a much lower number of myopes he concluded that there was a high proportion of myopics among cases of aphakic detachment. Hyams and others (1975) give an incidence of 6.7 per cent for myopia above $-6 \cdot 00$.

The procedure for cataract extraction in our group did not differ radically from that of others and no cases had prophylactic retinal treatment. Thus high myopia is undoubtedly a cause for concern when cataract extraction is considered. The reports of Schepens (I95I) and Hyams and others (1975) confirm this. The finding of Benson, Grand, and Okun (1975) that prophylactic retinal surgery lowers the incidence of aphakic detachment must therefore be heeded. Barraquer (1958) found a higher incidence of detachment among emmetropics because all the high myopes had had precataract extraction scleral resections.

Cataract extraction was bilateral in 5 per cent of our 944 eyes and the incidence of detachment among the bilateral cases was $11 \cdot 7$ per cent. This would be expected as the figure is approximately

Table XII Visual acuity after retinal surgery in 62 eyes

\begin{tabular}{ll}
\hline Acuity & $\begin{array}{l}\text { No. (per cent) } \\
\text { of eyes }\end{array}$ \\
\cline { 1 - 1 } HM to CF & $25(40 \cdot 4)$ \\
$6 / 60-6 / 36$ & I4 $(22 \cdot 5)$ \\
$6 / 24-6 / 18$ & I $(17 \cdot 8)$ \\
$6 / 12-6 / 6$ & 12 $(19 \cdot 3)$ \\
\hline Total & $62(100)$
\end{tabular}

$\mathrm{HM}=$ hand movements $; \mathrm{CF}=$ counting fingers

Table XIII Comparison of management of cases of cataract and of surgical technique in extractions in 1920 with those in 1960s

\begin{tabular}{|c|c|c|}
\hline & $1920 s$ & 1960s \\
\hline \multirow{10}{*}{$\begin{array}{l}\text { Time to operate } \\
\text { Average age } \\
\text { Extracapsular } \\
\text { Intracapsular } \\
\text { Zonulytic enzyme } \\
\text { Sutures } \\
\text { Ab. externo incision } \\
\text { Cryoextraction } \\
\text { Prophylactic retina } \\
\text { treatment } \\
\text { Incidence of detachment }\end{array}$} & Mature cataract & Immature to mature \\
\hline & 65 plus & 65 minus \\
\hline & Majority & Minority \\
\hline & Minority & Majority \\
\hline & None & 40 per cent \\
\hline & $\circ$ to $I$ & 2 to 7 \\
\hline & None & Over 50 per cent \\
\hline & None & 55 per cent \\
\hline & None & Minimal \\
\hline & $2 \cdot 2$ per cent & 5.7 per cent $(1967-9)$ \\
\hline
\end{tabular}


twice the incidence of unilateral cases (5.7 per cent). Shapland (I96I) noted in his series that detachment was commoner in men, and this was so in our series.

According to Hirsch (1964) fewer than I per cent of people have degenerative myopia and 15 per cent have myopia of more than $-\mathbf{r} \cdot 00$. Sorsby, Sheridan, Leary, and Benjamin (1960) consider that only 3 per cent of younger myopes are outside the range of -4.00 to $+6 \cdot 00$. Thus, bearing in mind the crude tolerance of the schematic aphakic eye, our analysis gives a distribution of cases of myopia presenting for cataract extraction of 20 per cent over -5.00 and 7.7 per cent over -10.00 . Therefore, using Hirsch's figures, we conclude that the incidence of cataract in degenerative myopia is high, which is a clinically accepted fact.

The incidence of detachment in aphakic myopic eyes may be given in different forms. Thus it can be given for each refractive group or for the whole group. The probability of having a detached retina is 40 per cent for over -10.00 and only 3.5 per cent for emmetropes and low myopes. The incidence of detachment based upon the corrected total becomes 2.3 per cent for emmetropia and up to $-4.00,0.6$ per cent for -5.00 and over, and 2.6 per cent for
-10.00 to $-20.00-$ a total of 5.5 per cent, which is the total true incidence of detachment for our whole series (Table I). Thus the expected refractions based upon the schematic eye equal the observed findings.

\section{Conclusions}

From this study of 944 cataract extractions the following conclusions are drawn.

The incidence of retinal detachment after modern cataract surgery is 5.7 per cent. The incidence of detachment is different in different refractive states, the incidence in cases whose preaphakic refraction is -10 dioptres or more being as high as 40 per cent.

It is also shown that high myopia not only predisposes to aphakic detachment but also to cataract itself.

Evidence is presented that the techniques of extraction do not influence the detachment rate nearly so much as the preoperative refractive state. Nevertheless there does appear to be a greater incidence of aphakic detachment in the current series of cases than in a series reported by Shapland (1934).

\section{References}

Barraquer, J. (1958) Anin. thér. Clin. Ophtal., 9, $29 \mathrm{I}$

BENSON, W. E., GRAND, M. G., and okUn, E. (1975) Arch. Ophthal., 93, 245

HirSCH, M. J. (1964) Amer. F. Optom., 41, 137

hyams, s. W., Bialik, M., and NeumanN, E. (I975) Brit. F. Ophthal., 59, 480

RUBEN, M. (1969) Proc. roy. Soc. Med., 62, 696

SHAPLAND, C. D. (1934) Trans. ophthal. Soc. U.K., 54, I79

- (1961) Trans. ophthal. Soc. Aust., 21, 61

SCHEPENS, C. L. (I95I) Arch. Ophthal., 45, I

SORSBY, A., SHERIDAN, M., LEARY, G. A., and BENJAMIN, B. (I960) Brit. med. F., I, I 394

TREISTER, G. (1972) Israel F. med. Sci., 8, 1434 